Review

International Journal of Biological Sciences ISSN 1449-2288 www.biolsci.org 2008 4(2): 116-125

CIvyspring International Publisher. All rights reserved

\title{
Relationship between calcium decoding elements and plant abiotic-stress resistance
}

\author{
Wei-Yi Song1, 6, Zheng-Bin Zhang ${ }^{1}$, Hong-Bo Shao ${ }^{2,3,5}$, Xiu-Lin Guo ${ }^{4}$, Hong-Xing Cao1, 6 , Hong-Bin Zhao1, 6 , \\ Zheng-Yan Fu1, 6 , Xiao-Jun $\mathrm{Hu}^{1,6}$
}

1. Center for Agricultural Resources Research, Institute of Genetic \&Developmental Biology, Chinese Academy of Sciences, Shijiazhuang, 050021, China

2. Binzhou University, Binzhou, 256603, China

3. State Key Laboratory of Soil Erosion and Dryland Farming on the Loess Plateau, Institute of Soil and Water Conservation, Chinese Academy of Sciences, Yangling712100, China

4. Institute of Genetics and Physiology, Hebei Academy of Agriculture and Forestry Sciences, Shijiazhuang 050051, China

5. Institute of Life Sciences, Qingdao University of Science\&Technology, Qingdao266042, China

6. Graduate University of Chinese Academy of Sciences, Beijing10049, China

Correspondence to: Dr. Professor Shao Hong-Bo and Zhang Zheng-Bin, E-mail: shaohongbo@qust.edu.cn, zzb@sjziam.ac.cn; Posting Address: Dr. Professor Shao Hong-Bo, Institute of Life Sciences, Qingdao University of Science \& Technology, Qingdao266042, China. Tel.: +86-532-84023984

Received: 2008.04.01; Accepted: 2008.04.25; Published: 2008.04.26

Serving as an important second messenger, calcium ion has unique properties and universal ability to transmit diverse signals that trigger primary physiological actions in cells in response to hormones, pathogens, light, gravity, and stress factors. Being a second messenger of paramount significance, calcium is required at almost all stages of plant growth and development, playing a fundamental role in regulating polar growth of cells and tissues and participating in plant adaptation to various stress factors. Many researches showed that calcium signals decoding elements are involved in ABA-induced stomatal closure and plant adaptation to drought, cold, salt and other abiotic stresses. Calcium channel proteins like AtTPC1 and TaTPC1 can regulate stomatal closure. Recently some new studies show that $\mathrm{Ca}^{2+}$ is dissolved in water in the apoplast and transported primarily from root to shoot through the transpiration stream. The oscillating amplitudes of $\left[\mathrm{Ca}^{2+}\right]_{\mathrm{o}}$ and $\left[\mathrm{Ca}^{2+}\right]_{\mathrm{i}}$ are controlled by soil $\mathrm{Ca}^{2+}$ concentrations and transpiration rates. Because leaf water use efficiency (WUE) is determined by stomatal closure and transpiration rate, so there may be a close relationship between $\mathrm{Ca}^{2+}$ transporters and stomatal closure as well as WUE, which needs to be studied. The selection of varieties with better drought resistance and high WUE plays an increasing role in bio-watersaving in arid and semi-arid areas on the globe. The current paper reviews the relationship between calcium signals decoding elements and plant drought resistance as well as other abiotic stresses for further study.

Key words: Calcium signals decoding elements; Stomatal closure; Water use efficiency (WUE); Abiotic stress-resistance

\section{Introduction}

Calcium signals decoding elements mainly include calcium-permeable ion channels, $\mathrm{Ca}^{2+} / \mathrm{H}^{+}$ antiporters and calcium ATPases, which have been investigated with electrophysiological, biochemical and molecular approaches [1]. A large body of electrophysiological studies elucidated that plants have $\mathrm{Ca}^{2+}$ channels with different types of gating mechanisms: ligand, voltage and stretch-activated [2]. However, only a limited number of genes encoding $\mathrm{Ca}^{2+}$ channels have been isolated and functionally expressed. In plants, calcium ion has emerged as a secondary messenger mediating the actions of many hormone and environmental factors, including biotic and abiotic stresses. It is reported that $\mathrm{Ca}^{2+}$ is involved in regulating such diverse and fundamental processes as cytoplasmic streaming, thigmotropism, gravitropism, cell division, cell elongation, cell differentiation, cell polarity, photomorphogensis, and plant defense and stress responses [3-6]. It is believed that calcium influx and cytoplasmic calcium $\left(\left[\mathrm{Ca}^{2+}\right]_{\mathrm{cyt}}\right)$ increases are important for guard cell ABA transduction, while $\mathrm{ABA}$ can regulate stomatal aperture in guard cells after inducing $\left[\mathrm{Ca}^{2+}\right]_{\mathrm{cyt}}$ to increase. It was also found recently in Arabidopsis thaliana that the oscillating amplitudes of $\left[\mathrm{Ca}^{2+}\right]_{\mathrm{o}}$ (extracellular $\mathrm{Ca}^{2+}$ concentration) and $\left[\mathrm{Ca}^{2+}\right]_{\mathrm{i}}$ (cytosolic $\mathrm{Ca}^{2+}$ concentration) are controlled by soil $\mathrm{Ca}^{2+}$ concentrations and transpiration rates. The phase and period of oscillations are likely determined by stomatal conductance [7], showing a close relationship between $\mathrm{Ca}^{2+}$ and transpiration stream as well as transpiration rate. Furthermore, leaf water use 
efficiency (WUE) (namely, transpiration efficiency = photosynthesis rate/ transpiration rate) is determined by transpiration rate and closely related with stomatal closure. Thus, the relationship between $\mathrm{Ca}^{2+}$ and leaf WUE should be intensively studied in future.

Among all the stresses to plant growth and development, drought is a major stress to agricultural production [8-14]. Plants synthesize ABA in response to drought, triggering a signaling cascade in guard cells that results in stomatal closure, thus reducing water loss, which may influence WUE in plants. In addition, drought is also related to salt stress, cold stress, high temperature stress, acid stress, alkaline stress, pathological reactions, senescence, growth, development, cell circle, UV-B damage, wounding, embryogenesis, flowering, signal transduction and so on $[8,9,13-23]$. Many advances in relation to this hot topic, including molecular mechanism of anti-drought and corresponding molecular breeding have emerged $[24,25]$ and calmodulin and calmodulin-related proteins (CMLs) were shown to participate in the complex responses of plant cells to environmental stress. This work helps provide a base of knowledge in stress physiology and valuable information for the technology for engineering improved stress-tolerance in important crop species [26].

With regard to the above description, this paper hopes to review advances in plant calcium signals decoding elements and the relationship between these elements and plant drought, salt and cold resistances, which will provide more valuable information for the research on plant abiotic stress resistance related with calcium signals decoding elements.

\section{Advances in plant calcium signals decoding elements}

Plant calcium signals decoding elements mainly include calcium permeable ion channels, $\mathrm{Ca}^{2+} / \mathrm{H}^{+}$ antiporters and $\mathrm{Ca}^{2+}$-ATPases [1]. Therefore, this paper firstly summarizes the main advances in three such kinds of elements.

\subsection{Calcium-permeable ion channels}

The previous definition of a $\mathrm{Ca}^{2+}$-permeable channel, simply as a channel permeable to $\mathrm{Ca}^{2+}$, merely assumed that its physiological function was to mediate $\mathrm{Ca}^{2+}$ influx from the apoplast into the cytoplasm. Although calcium-permeable channels have been investigated with electrophysiological, biochemical and molecular approaches, only a limited number of genes encoding $\mathrm{Ca}^{2+}$-permeable channels have been isolated and functionally studied. It was found that the importance of the cellular location of ion channels in determining stimulus specificity is emphasized by a study of $\mathrm{Ca}^{2+}$-mediated stomatal closure in tobacco. Removal of extracellular $\mathrm{Ca}^{2+}$ with the chelator EGTA or blockage of entry with a number of ion channel blockers suggested that low temperature-induced closure primarily involved in entry of $\mathrm{Ca}^{2+}$ across the plasma membrane, while intracellular mobilization appears to dominate if stomatal closure is initiated with ABA or mechanical stimulus. Amtmann et al [27] found that a wheat gene LCT1, encoding a low-affinity cation transporter, could complement a yeast mutant disrupted in the MIDI gene, which encodes a stretch-activated $\mathrm{Ca}^{2+}$ permeable non-selective cation channel. AtTPC1 (Arabidopsis two-pore voltage-gated channel 1), encoding a two-pore voltage-gated channel with high affinity for $\mathrm{Ca}^{2+}$ permeation, was found to rescue the $\mathrm{Ca}^{2+}$ uptake activity of a yeast mutant cch1 (which encodes a homologous L-type $\mathrm{Ca}^{2+}$ channel). $\left[\mathrm{Ca}^{2+}\right]_{\mathrm{cyt}}$ was enhanced by overexpressing of AtTPC1 or suppressed by antisense expression of it under sucrose stress. A unique gene in Arabidopsis, TPC1 (At4 g03560), whose general structure resembles that of the pore-forming subunits of mammalian and yeast $\mathrm{Ca}^{2+}$ channels that contain four Shaker-like domains, shows some sequence similarity. TPC1 expression enhances $\mathrm{Ca}^{2+}$ uptake in yeast $\mathrm{Ca}^{2+}$-channel mutant. OsTPC1, the homolog of AtTPC1, was also identified and characterized [28]. In 2005, the TaTPC1 gene, encoding a $\mathrm{Ca}^{2+}$ permeable channel, was cloned from wheat and located on the plasma membrane through the application of a TATPC1-GFP fusion protein. Expression of TaTPC1 in the yeast mutant lacking $\mathrm{CCH} 1$ (homologous to the 1-subunit of a voltage-gated $\mathrm{Ca}^{2+}$ channel) can recover its growth through functional complementation, and TaTPC1-overexpression in transgenic plants could accelerate the stomatal closing in the presence of $\mathrm{Ca}^{2+}$ when compared with control plants, indicating that the overexpression of TaTPC1 accelerated stomatal closing in the presence of $\mathrm{Ca}^{2+}$ [29]. It is also reported that plasma membrane calcium can transduce intracellular signaling and may exert effects on metabolism, gene expression and integrated physiological processes including cell division and cell elongation through regulating $\left[\mathrm{Ca}^{2+}\right]_{\mathrm{cyt}}$ [30]. Kinesin-like calmodulin binding protein (KCBP) is a microtubule motor protein involved in the regulation of cell division and trichome morphogenesis. A novel KCBP-interacting $\mathrm{Ca}^{2+}$ binding protein (KIC) with its single EF-hand motif, binds $\mathrm{Ca}^{2+}$ at a physiological concentration, suggesting that KIC modulates the activity of KCBP in response to changes in cytosolic $\mathrm{Ca}^{2+}$ and regulates trichome morphogenesis[31]. It is thought that the inward $\mathrm{Ca}^{2+}$ current, which generates the $\left[\mathrm{Ca}^{2+}\right]_{\text {cyt }}$ gradient, is mediated by the clustering of 
catalytically active (perhaps mechanosensitive) $\mathrm{Ca}^{2+}$ channels at the apex of the root hair [32-34]. It is noteworthy that these channels are inhibited by $\mathrm{La}^{3+}$ but not by nifedipine or verapamil. A hyperpolarization-activated $\mathrm{Ca}^{2+}$-permeable channel, which can be suppressed by EGTA, trivalent cations, verapamil, nifedipine or diltiazem, was identified on the plasma membrane of Lilium davidii $D$ pollen protoplasts with whole-cell patch-clamp recording. This primary evidence indicates the presence of a voltage-dependent $\mathrm{Ca}^{2+}$-permeable channel, whose activity may be regulated by extracellular $\mathrm{CaM}$ in pollen cells [35].

\section{2 $\mathrm{Ca}^{2+} / \mathrm{H}^{+}$antiporters}

The $\mathrm{Ca}^{2+} / \mathrm{H}^{+}$antiporter plays a key role together with $\mathrm{Ca}^{2+}$-ATPase in the accumulation of $\mathrm{Ca}^{2+}$ in vacuoles which constitute the primary pool of $\mathrm{Ca}^{2+}$ among several organelles of plants. The $\mathrm{Ca}^{2+} / \mathrm{H}^{+}$ antiporters are driven by a $\mathrm{pH}$ gradient generated by vacuolar proton pumps. Molecular cloning of the antiporters from Saccharomyces cerevisiae, Arabidopsis thaliana and mung bean revealed that the antiporter is a highly-hydrophobic protein with an acidic motif in the centre. The $\mathrm{Ca}^{2+}$-transport activity and intracellular localization of the translation product of cDNA for mung bean $\mathrm{Ca}^{2+} / \mathrm{H}^{+}$antiporter (VCAX1) were examined. When the cDNA was expressed in Saccharomyces cerevisiae that lacked its own genes for vacuolar $\mathrm{Ca}^{2+}$-ATPase and the antiporter, VCAX1 complemented the active $\mathrm{Ca}^{2+}$ transporters, and the microsomal membranes from the transformant showed high activity of the $\mathrm{Ca}^{2+} / \mathrm{H}^{+}$antiporter [36]. $\mathrm{Ca}^{2+} / \mathrm{H}^{+}$antiporters may play an important role in specifying the duration and amplitude of specific cytosolic $\mathrm{Ca}^{2+}$ fluctuations through regulating $\mathrm{Ca}^{2+}$ efflux $[1,37]$. The first plant $\mathrm{Ca}^{2+} / \mathrm{H}^{+}$antiporter was cloned by its ability to suppress the $\mathrm{Ca}^{2+}$-hypersensitive phenotype of a Saccharomyces cerevisiae mutant. These genes have been termed as "cation exchangers" (CAX) [38]. CAX1 from Arabidopsis thaliana is a high-capacity and low-affinity $\mathrm{Ca}^{2+}$ transporter, which has been shown to be localized in the plant vacuole [39] and its activity appears to be regulated by a N-terminal autoinhibitory domain [40, 41]. Arabidopsis has up to 12 putative $\mathrm{Ca}^{2+} / \mathrm{H}^{+}$cation antiporters (CAX1-11 and MHX) [42]. The Arabidopsis $\mathrm{Ca}^{2+} / \mathrm{H}^{+}$antiporter, CAX1, is a high-capacity and low-affinity $\mathrm{Ca}^{2+}$ transporter and several CAX1-like transporters are found in Arabidopsis. Several results suggest that CAX1 is regulated by several signaling molecules that converge on the $\mathrm{N}$-terminus of CAX1 to regulate $\mathrm{H}^{+} / \mathrm{Ca}^{2+}$ antiporter [43]. Through using site-directed mutagenesis, 31 mutations in the repeats of the Oryza sativa CAX were generated, which translocate $\mathrm{Ca}^{2+}$ and $\mathrm{Mn}^{2+}$. Mutant exchangers were expressed in a Saccharomyces cerevisiae strain that is sensitive to $\mathrm{Ca}^{2+}$ and $\mathrm{Mn}^{2+}$ because of the absence of vacuolar $\mathrm{Ca}^{2+}$-ATPase and the $\mathrm{Ca}^{2+} / \mathrm{H}^{+}$exchanger. In CAX1, the 9-amino acid calcium domain exists in the hydrophilic loop between TM1 and TM2. This domain is thought to be involved in the selection of $\mathrm{Ca}^{2+}$; although the sequence has not been found in other CAXs. The C domain located in TM4 may be involved in the selection of $\mathrm{Mn}^{2+}$ by Arabidopsis CAX2, which is the only plant CAX known to be capable of $\mathrm{Mn}^{2+}$ transport. Based on some results, the 451-amino acid protein OsCAX1a was predicted to have $11 \mathrm{TMs}$, like other CAX proteins $[44,45]$.

\section{3 $\mathrm{Ca}^{2+}$-ATPases}

Calcium pumps ( $\mathrm{Ca}^{2+}$-ATPases) belong to the superfamily of P-type ATPases that directly use ATP to drive ion translocation. Two distinct $\mathrm{Ca}^{2+}$ pump families have been proposed on the basis of protein sequence identity [46, 47]. Members of the type IIA and IIB families, respectively, include the ER-type calcium ATPases (ECAs) and the autoinhibited $\mathrm{Ca}^{2+}$-ATPases (ACAs). In Arabidopsis, there are four ECA- and ten ACA-type calcium pumps [48]. Isoform ECA1 appears to be located in the ER, as determined by membrane fractionation and immunodetection [49]. However, the potential for other isoforms targeting to non-ER locations must be considered. In tomato, there is evidence from membrane fractionation and immunodetection, suggesting that related ER-type calcium pumps (LCA1-related) are present in the vacuolar and plasma membranes [50]. In wheat root, a $\mathrm{Ca}^{2+}$-ATPase in plasma membranes was characterized [51], and two endomembrane $\mathrm{Ca}^{2+}$ transporters were located in different cellular compartments: the secondary $\mathrm{H}^{+} / \mathrm{Ca}^{2+}$ antiport located in the vacuolar membranes, and the primary $\mathrm{Ca}^{2+}$-ATPases located in the endoplasmic reticulum.

\section{Calcium signals decoding elements and plant drought resistance}

Drought serves as a major stress factor in inhibiting plant growth and development and productivity. As shown in many studies in recent years, exogenous $\mathrm{Ca}^{2+}$ can enhance plant drought resistance, inhibit the synthesis of activating oxides, protect the structure of cellular plasma membranes, and maintain normal photosynthesis as well as regulate the metabolism of plant hormone and other important chemicals. In addition, as a second messenger, cellular $\mathrm{Ca}^{2+}$ also transmits drought signals, thus regulating the physiological responses induced by drought stress [52-54]. The relationship 
between the nucleus of wheat seedling and $\mathrm{Ca}^{2+}$ under drought stress was examined with the cytochemical method of improved calcium antimonate precipitation. The results showed that there was a small concentration of $\mathrm{Ca}^{2+}$ in the nucleus, the nucleus was shaped like a ball and the chromatin was scattered. The longer the duration of drought stress the higher the free $\mathrm{Ca}^{2+}$ concentration in nucleus and the more serious the ultrastructure of the nucleus; meanwhile, the membrane of the nucleus wrinkled, the chromatin seriously agglutinated, and the shape of the nucleus was abnormal until its final disintegration [55]. It was also suggested that $\mathrm{Ca}^{2+} / \mathrm{CaM}$ messenger system was involved in controlling stress resistance of rice seedling, blocking messenger transduction, drought resistance, salt resistance and decreasing chilling resistance [56]. It was also indicated that $\mathrm{Ca}^{2+}$ treatment increased protection against membrane lipid peroxidation and stability of membranes and therefore resulted in the increase of drought resistance of rice seedlings [57]. It was also found in wheat that $\mathrm{Ca}^{2+}$ appeared to reduce the devastating effects of stress by elevating the content of proline and glycine betaine, thus improving the water status and growth of seedlings and minimizing the injury to membranes [58]. All the above-mentioned results showed that $\mathrm{Ca}^{2+}$ plays important roles in plant responses to drought resistance.

WUE is given much attention as a physiological trait related to plant drought resistance. Especially, the molecular research regarding the enhancement of WUE playing a crucial part in the selection and cultivation of drought-resistant or drought-tolerant crop varieties. When breeding for drought tolerance, biomass productivity and WUE are considered as fundamental agronomic characteristics [59].

As a kind of signaling substance, $\mathrm{Ca}^{2+}$ is closely related with various abiotic stress resistance for plants. As a member of signaling networks, the cellular $\mathrm{Ca}^{2+}$ signal pathways are mainly regulated by special proteins called $\mathrm{Ca}^{2+}$ signals decoding elements, which are also responsible for $\mathrm{Ca}^{2+}$ transportation. It has also been well established that regulation of stomatal aperture is $\mathrm{Ca}^{2+}$-dependent, with stimuli such as ABA and extracellular $\mathrm{Ca}^{2+}$ evoking a rise in $\left[\mathrm{Ca}^{2+}\right]_{\mathrm{cyt}}$ that precedes the loss of turgor by the surrounding guard cells. It was also reported that ABA induces an increase in $\left[\mathrm{Ca}^{2+}\right]_{c y t}$ in guard cells, which precedes the reduction in stomatal aperture [60]. Therefore it is believed $\left[\mathrm{Ca}^{2+}\right]_{\mathrm{cyt}}$ leads to the reduction in stomatal aperture [61]. In addition, according to some relevant research, $\mathrm{Ca}^{2+}$ is involved into ABA-induced signal transduction in guard cells, thus directly regulating stomatal conductance (Fig. 1) [62, 63] and (Fig. 2) [64].

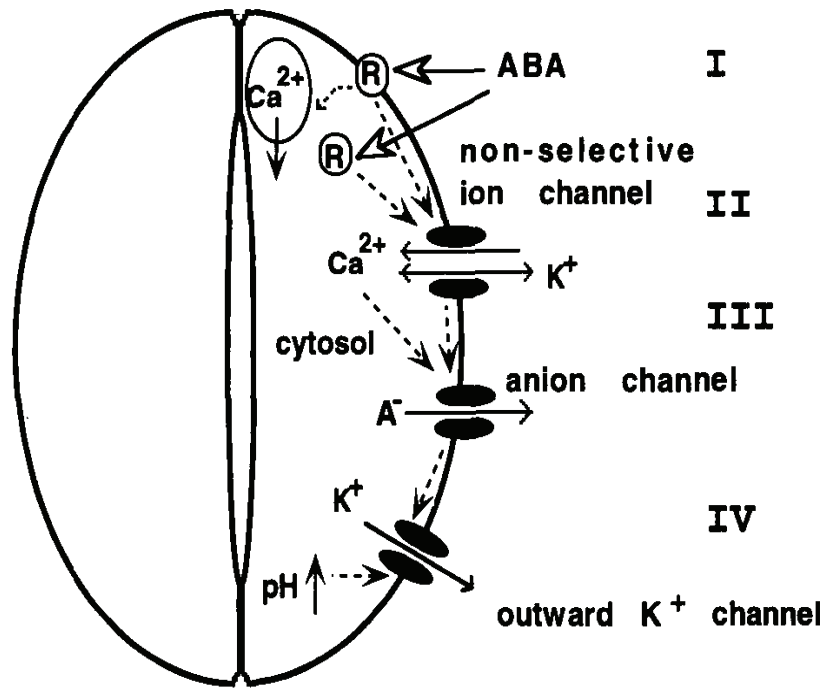

Fig. 1 The ABA-induced $\mathrm{Ca} 2+$ signal transduction in plant guard cells modified from $[62,63]$.

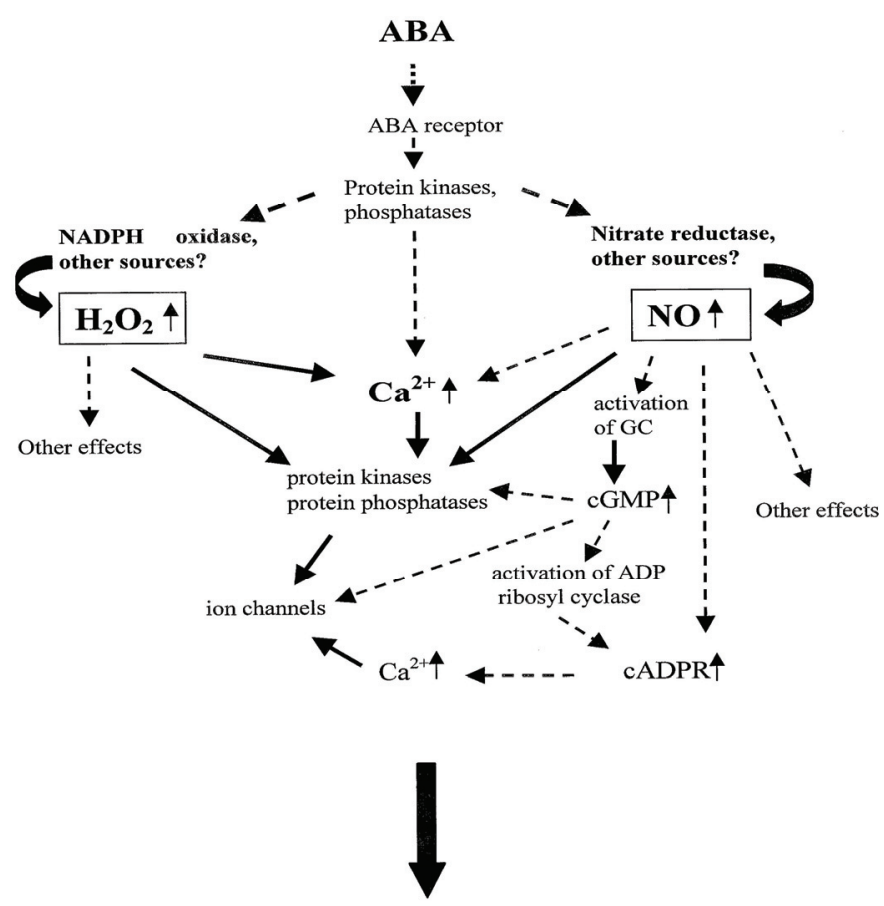

Stomatal closure

Fig. 2 The pattern and process of the ABA-induced signal transduction in plant cells modified from $[64,115]$.

What's more, $\mathrm{Ca}^{2+} / \mathrm{CaM}$ were indicated to participate in the process of ABA-induced drought signal transferring under PEG stress, while ABA synthesis was related with cytoplasmic $\mathrm{Ca}^{2+}$ concentrations [65]. It was reported that ABA triggers an increase in cytosolic calcium in guard cells, having been proposed to include $\mathrm{Ca}^{2+}$ influx across the plasma membrane [66]. ABA is known to evoke increases in cytosolic-free $\left[\mathrm{Ca}^{2+}\right]$, which is dependent 
on flux through $\mathrm{Ca}^{2+}$ channels in the plasma membrane and release from intracellular $\mathrm{Ca}^{2+}$ stores [66-69]. It has been known for some time that in guard cells, membrane hyperpolarization is directly associated with the elevation of $\left[\mathrm{Ca}^{2+}\right]_{\mathrm{cyt}}$ that follows ABA application [67]. Allen et al (2001) [70] showed that specific patterns of $\mathrm{Ca}^{2+}$ elevation may be involved in controlling both the stomatal closure response and the final steady state of stomatal aperture. A number of studies have shown that cytosolic-free concentration of calcium $\left(\left[\mathrm{Ca}^{2+}\right]_{\mathrm{cyt}}\right)$ plays a central role in stomatal movement, and the change in $\left[\mathrm{Ca}^{2+}\right]_{\mathrm{cyt}}$ regulates stomatal opening or closing [60, 71-73]. Further studies have established a close relationship between $\left[\mathrm{Ca}^{2+}\right]_{\text {cyt }}$ oscillation and stomatal status [70, 74, 75]. Relatively lower extracellular concentrations of calcium $\left(\left[\mathrm{Ca}^{2+}\right]_{\mathrm{ext}}\right)$ have been shown to induce $\left[\mathrm{Ca}^{2+}\right]_{\mathrm{cyt}}$ increases or oscillations, resulting in stomatal closure or aperture fluctuations [70]. In addition, $\mathrm{Ca}^{2+}$ is dissolved in water in the apoplast (extracellular space) and transported primarily from the root to the shoot through the transpiration stream [76, 77-82]. The transpiration rate is governed by stomatal conductance, which displays diurnal oscillations [83]. It was also found recently in Arabidopsis thaliana that the oscillating amplitudes of $\left[\mathrm{Ca}^{2+}\right]_{\mathrm{o}}$ (extracellular $\mathrm{Ca}^{2+}$ concentration) and $\left[\mathrm{Ca}^{2+}\right]_{\mathrm{i}}$ (cytosolic $\mathrm{Ca}^{2+}$ concentration) are controlled by soil $\mathrm{Ca}^{2+}$ concentrations and transpiration rates. The phase and period of oscillations are likely determined by stomatal conductance [7]. These results show a close relationship between $\mathrm{Ca}^{2+}$ and transpiration steam as well as transpiration rate. Thus, relationship between $\mathrm{Ca}^{2+}$ and leaf WUE should be investigated because leaf WUE is determined by transpiration rate and closely related with stomatal closure.

From the results of $\mathrm{Ca}^{2+}$ channel protein research in Arabidopsis and other plants, we can conclude that the genes encoding these proteins may belong to a certain gene family, and play an important part in plant responses to various stress resistances of plants $[11,28,29,38,84]$. In 2005, Wang et al. of our institute cloned TaTPC1 gene, encoding a $\mathrm{Ca}^{2+}$-permeable channel from wheat and located it on the plasma membrane through the application of a TATPC1-GFP fusion protein. Expression of TaTPC1 in the yeast mutant lacking CCH1 (homologous to the 1-subunit of a voltage-gated $\mathrm{Ca}^{2+}$ channel) can recover its growth through functional complementation, and TaTPC1-overexpression in transgenic plants could accelerate the stomatal closing in the presence of $\mathrm{Ca}^{2+}$ when compared with the control plants, indicating that the overexpression of TaTPC1 accelerated stomatal closing in the presence of $\mathrm{Ca}^{2+}$ [29]. What's more, we also implemented research work concerning wheat WUE evolution, gene location and molecular markers [85-88]. Currently, we conduct our research on the relationship between wheat $\mathrm{Ca}^{2+}$ channel proteins and leaf WUE as well as whole plant WUE by applying verapamil (a non-special inhibitor to $\mathrm{Ca}^{2+}$ channels) and $\mathrm{LaCl}_{3}$ (a special inhibitor to $\mathrm{Ca}^{2+}$ channels), already showing there exist differences between the WUE of dry-land wheat varieties and wetland ones in the presence of both inhibitors (data not shown). Meanwhile, we are currently implementing the functional research of wheat $\mathrm{Ca}^{2+}$ channels and identifying their distribution in different organs, so that the gene cloning of such channels can be further conducted.

\section{Calcium signals decoding elements and plant cold-resistance}

It is commonly held that $\mathrm{Ca}^{2+}$ channels play tremendous roles in the growth of root hairs and the low temperature acclimation of chilling-resistant plants. It is concluded that activity and stability of $\mathrm{Ca}^{2+}$-ATPase under $2^{\circ} \mathrm{C}$ low temperature are the key factors in the development of cold resistance of winter wheat [89]. It is suggested that the cold-resistant agent CR-4 plays a momentous role in stabilizing plasma membrane $\mathrm{Ca}^{2+}$-ATPase under low temperature stress, indicating that the $\mathrm{Ca}^{2+}$-ATPase activity was mainly localized at the plasma membrane in wheat seedling cells growing at normal temperatures [90]. A model of calcium-permeable channels involved in plant temperature sensing was established based on the fact that calcium influx into the cytoplasm is mediated by calcium-permeable channels, which are assumed to be solely dependent on cooling rate $(\mathrm{dT} / \mathrm{dt})$ and calcium efflux is mediated by calcium pumps, which have been shown to be dependent on absolute temperature (T). Such a model suggests that the primary temperature sensor in plants might be a $\mathrm{Ca}^{2+}$-permeable channel [91], indicating such channel proteins may participate in plant responses to cold stresses. It is also demonstrated in alfalfa as well as in Arabidopsis that $\mathrm{Ca}^{2+}$ influx acts as a signal transduction component in gene activation at low temperature [92]. It was found that the addition of $\mathrm{Ca}^{2+}$ chelators prevent cold acclimation and the expression of cold-regulated genes [93], while it was also found that addition of $\mathrm{Ca}^{2+}$ ionophore induces the expression of cold acclimation-specific genes at $25^{\circ} \mathrm{C}$ [94]. From studies on Arabidopsis mutants displaying reduced tonoplast $\mathrm{Ca}^{2+} / \mathrm{H}^{+}$antiport (CAX1) activity, it appears that CAX1 participates in the development of the cold acclimation response [95]. It was reported that when exposed to cold conditions, the $\mathrm{Ca}^{2+}$ 
concentration in cold-insensitive plants has been transiently increased, suggesting that $\mathrm{Ca}^{2+}$ acts as a second messenger during cold acclimation [94, 96, 97]. Therefore, with regard to the above-mentioned description, it can be equally inferred that $\mathrm{Ca}^{2+}$ transporters may be involved in plant responses to such other stresses as drought, salt and water deficit.

\section{Calcium signals decoding elements and plant salt resistance}

When $\mathrm{Ca}^{2+}$ is in deficit, plants are more susceptible to damage by low $\mathrm{pH}$ or high salt. Numerous results suggest that external and apoplastic $\mathrm{Ca}^{2+}$ directly alleviates symptoms produced by ion stresses or mineral toxicities, such as proton, $\mathrm{Na}^{+}, \mathrm{Al}^{3+}$, and $\mathrm{Cl}^{-}$toxicities, and $\mathrm{Ca}^{2+}$ also helps to establish a favorable $\mathrm{K}^{+}$: $\mathrm{Na}^{+}$ratio under salt stress [98].

It is suggested that intracellular calcium signaling through a calcineurin-like pathway mediates the beneficial effect of calcium on plant salt tolerance [99]. A salt stress induced $\mathrm{Ca}^{2+}$-dependent signaling network was described and illustrated in detail to mediate $\mathrm{Na}^{+}$homeostasis and salt tolerance, indicating that $\mathrm{Ca}^{2+}$ transporters are closely related to plant salt tolerance. It was also suggested that CaM activation might be necessary in calcium promotion of the accumulation of proline in fig calli, and the addition of calcium to media alleviated the inhibition of fig callus growth under salt stress [100], demonstrating that $\mathrm{CaM}$ might act jointly with $\mathrm{Ca}^{2+}$ under the support of calcium signals decoding elements in plant responses to salt stress. It was found that in barley roots, the activation of tonoplast $\mathrm{H}+-\mathrm{ATPase}$ and the regulation of $\mathrm{Na}^{+}$and $\mathrm{K}^{+}$uptake under $\mathrm{NaCl}$ stress may be related to $\mathrm{Ca}^{2+}-\mathrm{CaM}$ system [52], showing that calcium signals decoding elements may participate in the process of plant signaling responses to salt stress through accordingly regulating cytosolic $\mathrm{Ca}^{2+}$ concentration. A number of studies by Jian-Kang Zhu and his co-workers also indicated that in Arabidopsis, $\mathrm{Ca}^{2+}$ signaling network is closely related with the activation of the salt overly sensitive (SOS) signal transduction pathway which regulates cellular $\mathrm{Na}^{+}$ and $\mathrm{K}^{+}$homeostasis [101-103]. It is reasonable to assume that the salt induced $\left[\mathrm{Ca}^{2+}\right]_{\mathrm{cyt}}$ transients detected in plant cells [96](Knight, 1996), and perhaps, a new $\left[\mathrm{Ca}^{2+}\right]_{\text {cyt }}$ steady-state in yeast are controlled by the ECA and ACA $\mathrm{Ca}^{2+}$-ATPases and CAX1 and 2 transporters [104]. It was also evident that some physiological functions and molecular properties of the nonselective cation channels (NSCCs) are directly correlated with a multitude of stress responses, growth and development, uptake of nutrients and calcium signaling [105]. Therefore, it can be concluded that both types of $\mathrm{Ca}^{2+}$ transporters, namely, $\mathrm{Ca}^{2+}$-ATPases and CAXs involve in plant responses to salt stresses through regulating $\left[\mathrm{Ca}^{2+}\right]_{\mathrm{cyt}}$, thus regulating cellular and intercellular $\mathrm{Ca}^{2+}$ signaling networks and improving resistances or tolerances.

\section{Conclusions}

It has been found by a growing number of studies that calcium plays a vital role in life processes by acting as a messenger to regulate plant growth and development, as well as by its response and adaptation to environmental stresses [11, 106]. From the above information, more evidence can be found for supporting the conclusion that calcium signals decoding elements, which could be activated by ABA-induced signaling transduction, can regulate some genes relating to leaf WUE through controlling cytosolic $\mathrm{Ca}^{2+}$ concentration to lead to stomatal closure. Namely, $\mathrm{Ca}^{2+}$ serves as a signaling messenger for ABA-induced stomatal closure. Based on this, it can be speculated that calcium signals decoding elements located on the plasma membrane also involve in ABA-induced stomatal closure, thus leading to the change of leaf WUE. ABA is an endogenous anti-transpirant that induces stomatal closure, thereby leading to water conservation and the change of WUE. It was reported more than $95 \%$ of the water that passes through plants exits via the stomatal pores, through which the vast majority of carbon dioxide required for photosynthesis enters. Stomata operate as miniature homeostatic sensory and effector systems that sense a number of stimuli to induce guard cell swelling or shrinking, resulting in stomatal opening or closing, and thus optimization of WUE, a measure of the efficiency with which plants facilitate $\mathrm{CO}_{2}$ influx at the expense of water loss [64]. Therefore, ABA-induced stomatal closure is closely related with WUE. From the above description, we have found that the changes in cytosolic $\mathrm{Ca}^{2+}$ concentration, especially such changes in guard cells can be regulated by ABA production, thus leading to the change of stomatal aperture [60]. Besides, cytosolic $\mathrm{Ca}^{2+}$ concentration can be regulated by $\mathrm{Ca}^{2+}$ transporters such as calcium-permeable ion channels, $\mathrm{Ca}^{2+} / \mathrm{H}^{+}$antiporters and $\mathrm{Ca}^{2+}$-ATPases, which are also called calcium decoding signals elements. Therefore, it can be suggested that calcium decoding signals elements, activated by ABA-induced signaling, involve in regulating WUE through controlling the influx and efflux of $\mathrm{Ca}^{2+}$ from guard cells. Namely, these elements may be involved in the midway process of ABA-induced stomatal closure. In addition, we also find some genes, which control other traits of plants, can actually indirectly or directly regulate plant WUE [107-109], and some of these genes can even regulate 
stomatal aperture and stomatal density [29, 108, 109], which are crucial to the change of WUE. Hence, it can be concluded that calcium decoding signals elements also involve in the change of plant WUE. It was also reported that in the presence of $\mathrm{Ca}^{2+}$, the overexpression of TaTPC1 (functioning in $\mathrm{Ca}^{2+}$ import in wheat cytosol) accelerated the stomatal closing. The phase and period of $\mathrm{Ca}^{2+}$ concentration oscillations are likely determined by stomatal conductance [7], which governs transpiration rate [83] by transporting $\mathrm{Ca}^{2+}$ primarily from the root to the shoot through the transpiration stream [76, 82]. Therefore, by a final analysis, it can be proposed that calcium decoding signals elements (including calcium-permeable ion channels, $\mathrm{Ca}^{2+} / \mathrm{H}^{+}$antiporters and $\mathrm{Ca}^{2+}$-ATPases) can regulate plant WUE by involving the midway process of ABA-induced stomatal closure and the change of plant WUE, such sequent process can be illustrated as the following:

ABA-induced signal transduction $\rightarrow$ The activation of calcium decoding signals elements $\rightarrow$ The change of cytosolic $\mathrm{Ca}^{2+}$ concentration $\left(\left[\mathrm{Ca}^{2+}\right]_{\mathrm{cyt}}\right)$ $\rightarrow \mathrm{Ca}^{2+}$ signaling transduction $\rightarrow$ The change of stomatal aperture $\rightarrow$ the change of transpiration stream $\rightarrow$ the change of transpiration rate $\rightarrow$ the change of transpiration efficiency $\rightarrow$ The change of plant WUE.

It is our current hypothesis about the physiological relationship between calcium signals decoding elements and WUE in plants. More details concerning its molecular mechanism need to be further studied and clarified and complemented. Plant WUE is an important index for measuring plant drought-resistant and yield. Water scarcity is a major factor limiting agricultural production all over the world [110-115]. With the change of global environment, the impact of drought stress on crop yield becomes more serious. Thus, for sustainable agricultural development, irrigation practices must be implemented on the basis of applying the available water resource more efficiently. WUE can be observed at several levels [111-115]. In recent years, numerous progresses have been made in the investigation of plant WUE, especially at the molecular level.

As to the relationship between calcium signals decoding elements and plant abiotic stress resistance, according to numerous evidence described above, our speculation is that under cold and salt stresses, these elements act jointly to control cellular and intercellular $\mathrm{Ca}^{2+}$ concentrations, thus accordingly regulating $\mathrm{Ca}^{2+}$ signaling networks and further improving plant tolerance or resistance to cold and salt stresses. In view of the principles of "cross-talking", "cross stress" and "cross-resistance" [111, 112], plant resistance or tolerance to various stresses may be closely interrelated and mutually affected. In addition, some of the above research also tells us that $\mathrm{Ca}^{2+}$-ATPases are involved in wheat cold resistance [89, 90]. According to this, it can also be speculated that $\mathrm{Ca}^{2+}$-ATPases may be involved in other plant stress resistance based on the principle of "cross resistance". As we know, the three kinds of calcium decoding signals elements have similar motifs (EF-hands and transmembrane structures) in their molecular structure. Therefore, it can be conjectured that calcium permeable channels and $\mathrm{Ca}^{2+} / \mathrm{H}^{+}$antiporters may also involve in plant stress resistance as $\mathrm{Ca}^{2+}$-ATPases do. Because the acquirement of the tolerance or resistance to a certain stress can induce the emergence of other kind of tolerance or resistance, $\mathrm{Ca}^{2+}$ may confer many kinds of resistances or tolerances to plants. Therefore, calcium signals decoding elements serve as important regulators for plant responses under various stresses.

As an important element for the improvement of plant tolerance or resistance to various stresses, $\mathrm{Ca}^{2+}$ participates in many processes of plant responses to stresses and plays vital roles in maintaining both cellular and intercellular ionic balances under stresses. What's more, $\mathrm{Ca}^{2+}$ is also considered to be related with the improvement of plant acclimation and adaptation to various environments [93]. Under normal growth conditions, $\mathrm{Ca}^{2+}$ is also required for plant basic physiological activities, so, it is also assumed as a regulator of life itself [98]. Therefore, it can be equally assumed that as controllers for $\mathrm{Ca}^{2+}$ concentrations, calcium signals decoding elements are also important regulators for the machinery of life, and they play pivotal roles under both normal and stress conditions. With the advancement of $\mathrm{Ca}^{2+}$ signaling network research, such assumption will be expressly confirmed with the discoveries and clarifications of more molecular mechanisms for $\mathrm{Ca}^{2+}$-dependent signaling networks.

\section{Abbreviations}

WUE: water use efficiency; AtTPC1: ${ }^{1}$ Arabidopsis two-pore voltage-gated channel; $\mathrm{ABA}$ : abscisic acid; $\left[\mathrm{Ca}^{2+}\right]_{\text {cyt }}$ and $\left[\mathrm{Ca}^{2+}\right]_{\mathrm{I}}$ : cytosolic $\mathrm{Ca}^{2+}$ concentration; $\left[\mathrm{Ca}^{2+}\right]_{\mathrm{o}}$ and $\left[\mathrm{Ca}^{2+}\right]_{\text {ext: }}$ extracellular $\mathrm{Ca}^{2+}$ concentration; EGTA: Ethyleneglycol-bis-(2-aminoethyl)-tetraacetic acid; TaTPC1: Triticum asetivum two-pore channel 1; GFP: green fluorescent protein; CaM: calmodulin; CAX: cation exchanger; NSCCs: nonselective cation channels.

\section{Acknowledgement}

We are grateful for the support from the National 863 Water saving of Important Item (2006AA100201) and National Science \& Technology 
Supporting Project (2007BAD69B01). Special thanks are given to Professor Deng Chu-Xia for the instructive suggestions and the critical comments from three referees.

\section{Conflict of interest}

The authors have declared that no conflict of interest exists.

\section{References}

1. Sanders D, Pelloux J, Brownlee C, Harper JF. Calcium at the Crossroads of Signaling. Plant Cell 2002; 14: S401-S417.

2. Piñeros $\mathrm{M}$, Tester M. Calcium channels in higher plant cells: selectivity, regulation and pharmacology. J Exp Bot. 1997; 48: 551-577.

3. Trewavas AJ, Malho R. $\mathrm{Ca}^{2+}$ signaling in plant cells: the big network! Cur Opin Plant Biol. 1998;1: 428-433.

4. Zielinski RE. Calmodulin and calmodulin-binding proteins in plants. Annu Rev Plant Physiol Plant Mol Biol. 1998; 49: 697-725.

5. Reddy ASN. Calcium: silver bullet in signaling. Plant Sci. 2000; 160: 381-404.

6. Malho R, Kaloriti D, Sousa E. Calcium and rhythms in plant cells. Biol Rhythm Res. 2006; 37: 297-314.

7. Tang RH, Han SC, Zheng HL, Cook WC, Choi CS, Woerner TE, Jackson RB, Pei ZM. Coupling diurnal cytosolic $\mathrm{Ca}^{2+}$ oscillations to the CAS-IP3 pathway in Arabidopsis. Science, 2007; 315: 1423-1426.

8. Shao HB, Liang ZS, Shao MA. Roles of ABA signal transduction during higher plant seed maturation and germination. For Stu China 2003; 5: 42-51.

9. Shao HB, Liang ZS, Shao MA. Changes of some physiological and biochemical indices for soil water deficits among 10 wheat genotypes at seedling stage. Colloids Surf B Biointer. 2005; 42: 107-113.

10. Shao HB, Liang ZS, Shao MA. Impacts of PEG-6000 pretreatment for barley (Hordeum vulgare L.) seeds on the effect of their marure embryo in vitro culture and primary investigation on its physiological mechanism. Colloids Surf B Biointer. 2005; 41: 73-77.

11. Shao HB, Chu LY, Lu ZH, Kang CM. Primary antioxidant free radical scavenging and redox signaling pathways in higher plant cells. Int J Biol Sci. 2008; 4: 8-14.

12. Glombitza S, et al. Crosstalk and differential response to abiotic and biotic stressors reflected at the transcriptional level of effector genes from secondary metabolism. Plant Mol Biol. 2004;54(6): 817-35.

13. Jiang D, Xie ZJ, Cao WX. Effects of post-anthesis drought and water logging on photosynthetic characteristics, assimilates transportation in winter wheat. Acta Agron Sin. 2004; 30: 175-182.

14. Jiang MY, Zhang JH. Abscisic acid and antioxidant defense in plant cells. Acta Bot Sin. 2004; 46: 1-9.

15. Mantyla E, Lang V, Palva T. Role of abscisic acid in drought-induced freezing tolerance, cold acclimation, and accumulation of LT178 and RAB18 proteins in Arabidopsis. Plant Physiol. 1995; 107: 141-148.

16. Niu FX, Hua XX, Guo XD. Studies on several physiological indexes of the drought resistance of sweet potato and its comprehensive evaluation. Acta Agron Sin. 1996; 22: 392-398.

17. Neumann P. Salinity resistance and plant growth revisited. Plant Cell Environ. 1997; 20: 1193-1198.

18. Mlot C. Plant biology in the genome era. Science 1998;281: 331-332.

19. Meyerowitz EM. Plants compared to animals: the broadest comparative study of development. Science 2002; 295: 1482-1485.
20. Munns R. Comparative physiology of salt and water stress. Plant Cell Environ, 2002; (25): 239-252.

21. Kong QQ, Hu CH, Dong ST. Evolution of root characters during all growth stage of maize cultivars in different eras in China. Acta Agron Sin. 2003; 29: 641-645.

22. Li YH, Wang W, Ma QJ. The osmotic adjustment and photosynthesis of a wheat cultivar Hanfeng9703 with high yield, drought resistance under drought stress. Acta Agron Sin. 2003; 29: 759-764.

23. Mahajan S, Tuteja N. Cold, salinity and drought stress: An overview. Arch Bioch. 2005; 444: 139-158.

24. Kasuga M, Liu Q, Miura S. Improving plant drought, salt, and freezing tolerance by gene transfer of a single-inducible transcription factor. Nat Biotechnol. 1999; 17: 287-291.

25. Liu XN, Baird V. Identification of a novel gene, HAABRC5, from Helianthus annuus (Asteraceae) that is upregulated in response to drought, salinity, and abscisic acid. Am J Bot. 2004; 91: 184-191.

26. Vanderbeld B, Snedden WA. Developmental and stimulus-induced expression patterns of Arabidopsis calmodulin-like genes CML37, CML38 and CML39. Plant Mol Biol. 2007; 64: 683-697.

27. Amtmann A, Fischer M, Marsh EL, Stefanovic A, Sanders D, Schachtman DP. The wheat cDNA LCT1 generates hypersensitivity to sodium in a salt-sensitive yeast strain. Plant Physiol. 2001; 126: 1061-1071.

28. Hashimoto K, Saito M, Matsuka H, Lida K, Lida H. Functional analysis of a rice putative voltage-dependent $\mathrm{Ca}^{2+}$ channel, OSTPC1, expressed in yeast cells lacking its homologous gene CCH1. Plant Cell Physiol. 2004; 45: 496-500.

29. Wang YJ, Yu JN, Chen T, Zhang ZG, Hao YJ, Zhang JS, Chen SY. Functional analysis of a putative Ca21 channel gene TaTPC1 from wheat. J Exp Bot. 2005; 56: 3051-3060.

30. Bush DS. Calcium regulation in plant cells and its role in signaling. Annu Rev Plant Physiol Plant Mol Biol. 1995; 46: 95-122.

31. Reddy VS, Day IS, Thomas T, Reddy ASN. KIC, a Novel $\mathrm{Ca}^{2+}$-Binding Protein with One EF-Hand Motif, Interacts with a Microtubule Motor Protein and Regulates Trichome Morphogenesis. Plant Cell 2004; 16: 185-200.

32. Garrill A, Jackson SL, Lew RR, Heath IB. Ion channel activity and tip growth: tip localized stretch-activated channels generate an essential $\mathrm{Ca}^{2+}$ gradient in the oomycete of Saprolegnia ferax. Eur J Cell Biol. 1993; 60: 358-365.

33. Levina NN, Lew RR, Heath IB. Cytoskeletal regulation of ion channel distribution in the tip-growing organism Saprolegnia ferax. J Cell Sci. 1994; 107: 127-134.

34. Taylor AR, Manison NFH, Fernandez C, Wood J, Brownlee C. Spatial organization of calcium signaling involved in cell volume control in the Fucus rhizoid. Plant Cell 1996; 8: 2015-2031.

35. Shang SL, Ma LG, Zhang HL, He RR, Wang XC, Cui SJ, Sun DY. $\mathrm{Ca}^{2+}$ Influx into Lily Pollen Grains Through a Hyperpolarization-activated $\mathrm{Ca}^{2+}$-permeable Channel Which Can be Regulated by Extracellular CaM. Plant Cell Physiol. 2005; 46: 598-608

36. Nakanishi HU, Tsuchiya T, Sasaki M, Nakanishi $Y$, Cunningham KW, Maeshima M. Functional expression of mung bean $\mathrm{Ca}^{2+} / \mathrm{H}^{+}$antiporter in yeast and its intracellular localization in the hypocotyl and tobacco cells. Eur J Biochem. 2000; 267: 3090-3098.

37. Harper JF. Dissecting calcium oscillators in plant cells. Trends Plant Sci. 2001; 6: 395-397.

38. Hirschi KD, Zhen RG, Cunningham KW, Rea PA. , Fink GR. CAX1, an $\mathrm{H}^{+} / \mathrm{Ca}^{2+}$ antiporter from Arabidopsis. Proc Natl Acad Sci. 1996; 93: 8782-8786.

39. Cheng NH, Pittman JK, Barkla BJ, Shigaki T, Hirschi KD. The Arabidopsis cax1 Mutant Exhibits Impaired Ion Homeostasis, 
Development, and Hormonal Responses and Reveals Interplay among Vacuolar Transporters. Plant Cell 2003; 15: 347-364.

40. Pittman JK, Hirschi KD. Regulation of CAX1, an Arabidopsis $\mathrm{Ca}^{2+} / \mathrm{H}^{+}$Antiporter. Identification of an N-Terminal Autoinhibitory Domain. Plant Physiol. 2001; 127: 1020-1029.

41. Pittman JK, Shigaki T. , Cheng N. H. , Hirschi K. D. Mechanism of N-terminal Autoinhibition in the Arabidopsis $\mathrm{Ca}^{2+} / \mathrm{H}^{+}$ Antiporter CAX1. J Biol Chem. 2002; 277: 26452-26459.

42. Mäser P, Thomine S, Schroeder JI. , Ward JM, Hirschi K, Sze H, Talke IN, Amtmann A, Maathuis FJM, Sanders D, Harper JF, Tchieu J, Gribskov M, Persans MW, Salt DE, Kim SA, Guerinot ML. Phylogenetic relationships within cation transporter families of Arabidopsis. Plant Physiol. 2001; 126: 1646-1667.

43. Cheng NH, Liu JZ, Nelson RS, Hirschi KD. Characterization of CXIP4, a novel Arabidopsis protein that activates the $\mathrm{H}^{+} / \mathrm{Ca}^{2+}$ antiporter, CAX1. FEBS Let. 2004; 559: 99-106.

44. Kamiya T, Maeshima M. Residues in internal repeats of the rice cation/ $\mathrm{H}+$ exchanger are involved in the transport and selection of cations. J Biol Chem. 2004; 279: 812-819.

45. Shigaki T, Pittman JK, Hirschi KD. Manganese specificity determinants in the Arabidopsis metal/H+ antiporter CAX2. J Biol Chem. 2003; 278: 6610-6617.

46. Geisler M, Axelsen KB, Harper JF, Palmgren MG. Molecular aspects of higher plant P-type $\mathrm{Ca}^{2+}$-ATPases. Biochim Biophys Acta. 2000; 1465: 52-78.

47. Axelsen KB, Palmgren MG. Inventory of the superfamily of P-type ion pumps in Arabidopsis. Plant Physiol. 2001; 126: 696-706.

48. Liang F, Cunningham KW, Harper JF, Sze H. ECA1 complements yeast mutants defective in $\mathrm{Ca} 2+$ pumps and encodes an endoplasmic reticulum-type Ca2+-ATPase in Arabidopsis thaliana. Proc Natl Acad Sci. 1997; 94: 8579-8584.

49. Hong B, Ichida A, Wang Y, Gens JS, Pickard BG, Harper JF. Identification of a calmodulin-regulated $\mathrm{Ca}^{2+}$-ATPase in the endoplasmic reticulum. Plant Physiol. 1999; 119: 1165-1176.

50. Ferrol N, Bennett AB. A single gene may encode differentially localized $\mathrm{Ca}^{2+}$-ATPases in tomato. Plant Cell 1996; 8: 1159-1169.

51. Olbe M, Widell S, Sommarin M. Active calcium transporters in isolated membranes of wheat root cells. J Exp Bot. 1997; 48: 1767-1777.

52. Zhang WJ, Zhang J, Liu F, Li GM, Guan JF. The relationship between $\mathrm{Ca}^{2+}$ and drought_resistance in plants. Chin Bull Bo. 2001;18: 473-478.

53. Zhang X, Zhang L, Dong FC, Gao JF, Galbraith DW, Song CP. Hydrogen peroxide is involved in abscisic acid-induced stomatal closure in Vicia faba. Plant Physiol. 2001; 126: 1438-1448.

54. Tuberosa R, Giuliani S, Parry MAJ, Araus JL. Improving water use efficiency in Mediterranean agriculture: what limits the adoption of new technologies? Ann Appl Biol. 2007; 2: 157-162.

55. Liu LJ, Li GM, Shang ZQ, Zhang H, Wang FR. The relationship between the nucleus of the wheat seedling and $\mathrm{Ca} 2+$ under water stress. Acta Agri Boreali-Sin. 2000; 15: 4-7.

56. Zong H. , Liu EE, Guo ZF, Li MQ. Enhancement of drought resistance of rice seedlings. J South China Agri Univ. 2000; 21: 63-65.

57. Lu SY, Li YC, Guo ZF, Li BS, Li MQ. Enhancement of drought resistance of rice seedlings by calcium. Chin J Rice 1993; 13: 161-164.

58. Nayyar H. Variation in osmoregulation in differentially drought-sensitive wheat genotypes involves calcium. Biol Plant. 2003; 47: 541-547.

59. Blum A. Selection for sustained production in water-deficit environments. Int Crop Sci. 1993; 1: 343-347.

60. McAinsh MR, Webb AAR, Taylor JE, Hetherington AM. Stimulus-induced oscillations in guard cell cytoplasmic free calcium. Plant Cell 1995; 7: 1207-1219.

61. Murata Y, Pei ZM, Mori IC, Schroeder J. Abscisic acid activation of plasma membrane $\mathrm{Ca}^{2+}$ channels in guard cells requires cytosolic $\mathrm{NAD}(\mathrm{P}) \mathrm{H}$ and is differentially disrupted upstream and downstream of reactive oxygen species production in abi1-1 and abi2-1 protein phosphatase $2 \mathrm{C}$ mutants. Plant Cell 2000; 13 : 2513-2523.

62. Schmidt C, Schelle I, Liao YH, Schroeder JI. Strong regulation of slow anion channels and abscisic acid signaling in guard cells by phosphorylation and dephosphorylation events. Proc Natl Acad Sci. 1995; 92: 9535-9539.

63. Ward JM, Pei ZM, Schroeder JI. Roles of ion channels in initiation of signal transduction in higher plants. Plant Cell 1995; 77: 833-844.

64. Neill SJ, Desican R, Clarke A, Hancock JT. Nitric oxide is a novel component of abscisic acid signaling in stomatal guard cells. Plant Physiol. 2002; 128: 13-16.

65. Li JM, Cui SP, Guan JF, Li MJ, Guo XL. The Relationship between ABA and Ca2+/CaM in Winter Wheat Seedlings under PEG Stress. Acta Agron Sin. 2002; 28: 537-540.

66. Pei ZM, Murata Y, Benning G, Thomine S, Klusener B, Allen GJ, Grill E, Schroeder JI. Calcium channels activated by hydrogen peroxide mediate abscisic acid signaling in guard cells. Nature, 2000; (406): 731-734.

67. Grabov A. , Blatt M. R. Membrane voltage initiates $\mathrm{Ca}^{2+}$ waves and potentiates $\mathrm{Ca}^{2+}$ increases with abscisic acid in stomatal guard cells. Proc Natl Acad Sci. 1998; 95: 4778-4783.

68. Hamilton DWA, Hills A, Köhler B, Blatt MR. $\mathrm{Ca}^{2+}$ channels at the plasma membrane of stomatal guard cells are activated by hyperpolarization and abscisic acid. Proc Natl Acad Sci. 2000; 97: 4967-4972.

69. Hetherington AM, Brownlee C. The generation of Ca2+ signals in plants. Annu Rev Plant Biol. 2004; 55: 401-427.

70. Allen GJ, Chu SP, Harrington CL, Schumacher K, Hoffman T, Tang YY, Grill E, Schroeder JI. A defined range of guard cell calcium oscillation parameters encodes stomatal movements. Nature 2001; 411: 1053-1057.

71. Blatt MR. Reassessing roles for $\mathrm{Ca} 2+$ in guard cell signalling. J Exp Bot. 1999; 50: 989-999.

72. Hetherington AM. Guard cell signalling. Cell 2001; 107: 711-714.

73. Schroeder JI, Allen GJ, Hugouvieux V, Kwak JM, Waner D. Guard cell signal transduction. Ann Rev Plant Physiol Plant Mol Biol. 2001; 52: 627-658.

74. Yang HM, Zhang XY, Wang GX. , Li Y, Wei XP. Cytosolic calcium oscillation may induce stomatal oscillation in Vicia faba. Plant Sci. 2003; 165: 1117-1122.

75. Yang HM. , Zhang XY, Wang GX. Cytosolic calcium oscillation signaling in guard cell. Plant Sci. 2004; 166: 549-556.

76. Hepler PK. Calcium: A Central Regulator of Plant Growth and Development. Plant Cell 2005; 17: 2142-2155.

77. White PJ. Characterization of a high-conductance, voltage-dependent cation channel from the plasma membrane of rye roots in planar lipid bilayers. Planta 1993; 191: 541-551.

78. White PJ. Characterization of a voltage-dependent cation channel from the plasma membrane of rye (Secale cereale L. ) roots in planar lipid bilayers. Planta 1994; 193: 186-193.

79. White PJ. Specificity of ion channel inhibitors for the maxi cation channel in rye root plasma membranes. J Exp Bot. 1996; 47: 713-716.

80. White PJ. Cation channels in the plasma membrane of rye roots. J Exp Bot. 1997; 48: 499-514.

81. White PJ. Calcium channels in the plasma membrane of root cells. Ann Bot-London, 1998; 81: 173-183.

82. White PJ, Broadley MR. Calcium in plant. Ann Bot. 2003; 92: 487-511.

83. Webb AAR. The physiology of circadian rhythms in plants. New Phytol. 2003; 160: 281-303.

84. Furuichi T, Cunningham KW, Muto S. A putative two pore channel AtTPC1 mediates $\mathrm{Ca}^{2+}$ flux in Arabidopsis leaf cells. 
Plant Cell Physiol. 2001; 42: 900-905.

85. Cao HX, Zhang ZB, Xu P, Chu LY, Shao HB , Lu ZH. Mutual physiological genetic mechanism of plant high water use efficiency and nutrition. Colloids Surf B Biointer. 2007; 57: 1-7.

86. Zhao $\mathrm{H}$, Zhang ZB, Xu P. Genetic correlation analysis between leaf water use efficiency and relevant physiological traits in wheat. Sci Agri Sin. 2006; 39: 1796-1803.

87. Zhang ZB, Xu P, Zhou XG, Dong BD. Advance in genetic improvement of water use efficiency in crops. Sci Agri Sin. 2006; 39: 289-294.

88. Zhang ZB, Shao HB, Xu P, Chu LY, Lu ZH, Tian JY. On evolution and perspectives of bio-watersaving. Colloids Surf B Biointer. 2007; 58: 1-9.

89. Liu W, Sun DL, Wang H. , Jian LC, Zhao KF. Comparison of Ca2+-ATPase Activity in Winter Wheat VS. Cold-sensitive Spring Seedling PIasmolemma of Cold-resistant wheat under $2^{\circ} \mathrm{C}$ Low Temperature. Acta Agron Sin. 2002; 28: 227-229.

90. Sun DL, Wang H, Jian LC. The stabilization on the plasmlemma calcium-pump ( $\mathrm{Ca}^{2+}$-ATPase) in winter wheat seedlings by the cold-resistant agent CR-4. Chin Bull Bot. 1998; 15: 50-54.

91. Plieth C. Temperature Sensing by Plants: Calcium-Permeable Channels as Primary Sensors-A Model. J Membr Biol. 1999; 172: 121-127.

92. Busconi $M$, Bosco $C D$, Crosatti $C$, Baldi $P$, Marè $C$, Grossi $M$, Mastrangelo AM, Rizza F, Cattivelli L, Stanca AM. The cold-regulated genes are involved in the physiological response of barley to cold environment. ICL Agri Sci. 2001; 14: 17-27.

93. Tähtiharju S, Sangwan V, Monroy AF, Dhindsa RS, Borg M. The induction of kin genes in cold-acclimating Arabidopsis thaliana. Evidence of a role for calcium. Planta 1997; 203: 442-447

94. Monroy AF, Dhindsa RS. Low-temperature signal transduction: induction of cold acclimation-specific genes of alfalfa by calcium at $25^{\circ} \mathrm{C}$. Plant Cell 1995;7: 321-331.

95. Catala R, Santos E, Alonso JM, Ecker JR, Zapater JMM. Mutations in $\mathrm{Ca}^{2+} / \mathrm{H}^{+}$transporter CAX1 increase CBF/DREB1 expression and the cold acclimation response in Arabidopsis. Plant Cell 2003; 15: 2940-2951.

96. Knight H, Trewavas A.J, Knight MR. Cold calcium signaling in Arabidopsis involves two cellular pools and a change in calcium signature after acclimation. Plant Cell, 1996; (8): 489-503.

97. Jian LC, Li JH, Chen WP, Li PH, Ahlstrand GG, Kao PY. Cytochemical localization of calcium and $\mathrm{Ca}^{2+}$-ATPase activity in plant cells under chilling stress: a comparative study between the chilling-sensitive maize and chilling-insensitive winter wheat. Plant Cell Physiol. 1999; 40: 1061-1107.

98. Plieth C. Calcium: Just Another Regulator in the Machinery of Life? Ann Bot. 2005;96: 1-8.

99. Liu JP, Zhu JK. A Calcium Sensor Homolog Required for Plant Salt Tolerance. Science 1998; 280: 1943

100.Wang LG, Liu YL, Ma K. The role of calcium in promotion of proline accumulation induced by stress in fig (Ficus carica L. ) cells. Acta Photophysiol Sin. 1999; 25(Suppl): S38-S42.

101.Zhu JK. Genetic analysis of plant salt tolerance using Arabidopsis. Plant Physiol. 2000; 124: 941-948.

102. Zhu JK. Plant salt tolerance. Trends Plant Sci. 2001; 6: 66-71.

103. Zhu JK, Liu J, Xiong L. Genetic analysis of salt tolerance in Arabidopsis: Evidence for a critical role to potassium nutriton. Plant Cell 1998;10: 1181-1191.

104.Sze H, Liang F, Hwang I, Curran AC, Harper JF. Diversity and regulation of plant $\mathrm{Ca} 2+$ pumps: insights from expression in yeast. Ann Rev Plant Physiol Plant Mol Biol. 2000; 51: 433-462.

105.Demidchik V, Maathuis FJM. Physiological roles of nonselective cation channels in plants: from salt stress to signalling and development. New Phytol. 2007; 175: 387-404.

106.Poovaiah BW, Reddy ASN. Calcium and signal transudation in plant. Crit Rev Plant Sci. 1993; 12: 185-211.

107.Sivamani E, Bahieldin A, Wraith JM, Niemi TA, Dyer WE, Hua
T, Ho D, Qu RD. Improved biomass productivity and water use efficiency under water deficit conditions in transgenic wheat constitutively expressing the barley HVA1 gene. Plant Sci. 2000; 155: 1-9.

108. Klein M, Barbeoch LP, Frelet A, Gaedeke N, Reinhardt D, Roeber BM, Forestier EMC. The plant multidrug resistance ABC transporter AtMRP5 is involved in guard cell hormonal signaling and water use. Plant J. 2003; 33: 119-129.

109. Masle J, Gilmore SR, Farquhar GD. The ERECTA gene regulates plant transpiration efficiency in Arabidopsis. Nature 2005; 436: 866-870.

110.Liu FL, Andersen MN, Jacobsen SE, Jensen CR. Stomatal control and water use efficiency of soybean (Glycine max L. Merr. ) during progressive soil drying. Environ Exp Bot. 2005; 54: 33-40.

111. Turner NC. Further progress in crop water relations. Adv Agron. 1997; 58: 293-338.

112.Knight H, Knight MR. Abiotic stress signaling pathways: specificity and cross talk. Trends Plant Sci. 2001; 6: 262-267.

113. Shao HB, Chu LY, Shao MA, Zhao CX. Advances in functional regulation mechanisms of plant aquaporins: Their diversity, gene expression, localization, structure and roles in plant soil-water relations. Mol Membr Biol. 2008; 25: 179-191.

114.Shao HB, Chu LY. Plant molecular biology in China: Opportunities and challenges. Plant Mol Biol Rep. 2005;23: 345-358.

115. Shao HB, Chu LY, Jaleel CA, Zhao CX. Water deficit-induced morphological changes in higher plants. C R Biol. 2008; 331: 215-225. 